\title{
Polimorfismo do Gene do Receptor de Progesterona (PROGINS) em Mulheres com Endometriose Pélvica
}

\author{
Progesterone Receptor Gene Polymorphism (PROGINS) in Women with Pelvic Endometriosis
}

Cristina Valletta de Carvalho, Paulo D’Amora, Hélio Sato, Manoel João Batista Castello Girão, Geraldo Rodrigues de Lima, Ismael Dale Cotrim Guerreiro da Silva, Eduardo Schor

\section{RESUMO}

\begin{abstract}
Objetivo: o objetivo do estudo foi verificar a prevalência do polimorfismo denominado PROGINS no gene do receptor de progesterona entre mulheres com endometriose em seus diferentes estádios. Métodos: estudo caso-controle desenvolvido entre novembro de 2003 e maio de 2004. Foram analisados os genótipos de 104 mulheres, das quais 66 com endometriose comprovada por videolaparoscopia (26 mulheres nos estádios I-II e 40 nos estádios III-IV) e 38 saudáveis. A inserção Alu de 306 pares de base no intron $G$ do gene do receptor de progesterona denominada PROGINS foi detectada por meio de reação em cadeia da polimerase e analisada em gel de agarose $2 \%$ corado com brometo de etidio. Para análise estatística foi utilizado o teste ANOVA paramétrico.

Resultados: as amostras pertencentes aos grupos endometriose estádios I-II (grupo EndoI) e estádios III-IV (grupo EndoII) tiveram significativo aumento na incidência do alelo polimórfico do receptor de progesterona em relação ao grupo controle: $27 \%$ no grupo EndoI, 38\% no EndoII e apenas $18 \%$ no grupo controle $(p<0,001)$. A prevalência da inserção, quando comparamos mulheres com endometriose, independente do estádio, com as do grupo controle, foi estatisticamente superior no grupo das doentes ( $p=0,0385)$.

Conclusão: há associação estatisticamente significante entre o polimorfismo PROGINS e a endometriose pélvica.
\end{abstract}

PALAVRAS-CHAVE: Endometriose. Receptor de progesterona. Polimorfismo gênico.

\section{Introdução}

A endometriose é doença estrogênio-dependente caracterizada por implantes ectópicos de endométrio no peritônio pélvico ou em vísceras. Na maioria dos casos está associada à dor pélvica e/ou à infertilidade.

Departamento de Ginecologia - Universidade Federal de São Paulo UNIFESP-EPM.

Correspondência:

Eduardo Schor

Setor de Algia Pélvica e Endometriose

Rua Pedro de Toledo, $781-4^{\circ}$ Andar -

Vila Clementino - 04023000 - São Paulo - SP

e-mail: schor.gineco@epm.br

Financiamento: FAPESP 03/04533-1
A teoria etiopatogênica mais aceita durante o século XX foi a proposta por Sampson ${ }^{1}$, que postulou que o refluxo transtubário de células endometriais viáveis seria a causa da moléstia. Entretanto, no início da década de 80 vários autores observaram que a menstruação retrógrada poderia ocorrer em até $80 \%$ de mulheres submetidas à cirurgia no período perimenstrual, porém apenas $15 \%$ desenvolvem endometriose. Assim, o refluxo transtubário de células endometriais não basta, por si só, para explicar a etiopatogenia da doença; de fato, novos fatores devem, estar, de alguma forma associados à menstruação retrógrada, visto que a prevalência do evento e a da doença são discordantes ${ }^{2-4}$.

A partir de então, novas teorias foram necessárias para explicar o aparecimento da doença em apenas uma parcela da população feminina. 
Alguns autores estudaram o endométrio tópico, acreditando que suas células se deslocariam do útero já com alterações que predisporiam à doença $^{5,6}$. De fato, alterações no ciclo celular, levando a aumento de proliferação ou diminuição na morte celular programada, foram descritas ${ }^{7-10}$.

A maior capacidade de degradação da matriz extracelular da mucosa tópica, bem como o aumento de fatores angiogênicos, já foram relatados e podem, de alguma forma, contribuir para o aparecimento da doença ${ }^{6}$. Sabe-se também que o endométrio das enfermas possui a enzima aromatase p450, Cyp19, que não existe no de mulheres sadias. Este distúrbio relacionado à síntese e à metabolização de estrogênios gera ambiente hiperestrogênico, de cunho proliferativo, contribuindo de forma importante para o estabelecimento da doença ${ }^{11}$.

Inúmeros autores já demonstraram a expressão exagerada de receptores de estrogênio nos implantes de endometriose, e também, o que parece importante, defeitos no receptor de progesterona ${ }^{12,13}$. As alterações, descritas acima, são conseqüência da anormalidade do efeito progestacional sobre o endométrio tópico e ectópico. A maior secreção de colagenases, bem como a menor expressão de seus fatores inibidores, a secreção de peptídeos angiogênicos, o controle do ciclo celular e a metabolização dos estrogênios nas células endometriais são, como se sabe, regulados pela progesterona. Alterações da sua função podem, portanto, facilitar o aparecimento da moléstia, porque, no sentido amplo, deixa de antagonizar os efeitos proliferativos dos estrogênios.

As ações biológicas da progesterona são mediadas por duas isoformas de seu receptor, respectivamente A e B. Em seres humanos os dois RNAs transcritos são gerados a partir de um único gene que tem, porém, regiões promotoras diferentes. Estruturalmente, as proteínas diferem apenas quanto à presença de 164 aminoácidos na região $\mathrm{N}$-terminal do receptor $\mathrm{B}^{14}$.

No endométrio ambos subtipos do receptor de progesterona são expressos, e a sua concentração varia de acordo com a fase do ciclo menstrual. Entretanto, parece que os efeitos antiproliferativos da progesterona sobre o endométrio são mediados principalmente pela isoforma A do receptor de progesterona. A ativação da isoforma $\mathrm{B}$, na ausência do receptor tipo A, leva a aumento da proliferação no epitélio. Portanto, havendo a predominância da isoforma $\mathrm{B}^{15}$, não há adequada ação da progesterona, especulando-se, desse modo, que talvez essa alteração esteja relacionada à gênese da endometriose.

Recentemente, vários polimorfismos do re- ceptor de progesterona têm sido descritos. Dentre eles destaca-se o polimorfismo PROGINS, que consiste em uma inserção Alu de 306 pb no intron G entre o exon 7 e 8 do gene do receptor de progesterona humano ${ }^{16}$. Rowe et al. ${ }^{17}$ observaram alterações fenotípicas decorrentes dos polimorfismos do gene do receptor de progesterona, sugerindo que esta inserção Alu seria responsável por alterações na transcrição do gene desse receptor, tanto por recombinação ou por alteração no splicing do transcrito primário.

O polimorfismo PROGINS tem sido estudado em associação com afecções estrogênio-dependentes $^{18-21}$. Wieser et al. $^{22}$ estudaram a freqüência desta mutação em mulheres com endometriose; encontraram-na em $28 \%$ dos casos e em apenas $14 \%$ das sadias.

Todos os dados indicam que uma mutação no gene do receptor da progesterona, seja qualquer uma das mencionadas acima, contribui para o desenvolvimento de doenças em tecidos hormôniodependentes, inclusive na endometriose.

Assim, propomos a investigar a prevalência do polimorfismo do receptor de progesterona denominado PROGINS em mulheres com e sem endometriose.

\section{Pacientes e Métodos}

O grupo de estudo foi composto por 66 pacientes com endometriose submetidas a videolaparoscopia, quando foram observadas lesões típicas e que foram biopsiadas para exame histopatológico. As pacientes foram divididas em três grupos, segundo o estadiamento da moléstia consoante os critérios da American Society for Reproductive Medicine ${ }^{23}$ : grupo EndoI, compreendendo 26 pacientes nos estádios I e II, e grupo EndoII com 40 pacientes nos estádios III e IV; o grupo controle foi formado por 38 mulheres na pósmenopausa. As pacientes do grupo controle não apresentaram histórico pregresso de dor pélvica crônica (dismenorréia e/ou dispareunia), queixa de infertilidade, bem como nenhuma doença ginecológica hormônio-dependente. O presente estudo foi analisado e aprovado pelo Comitê de Ética em Pesquisa da Universidade Federal de São Paulo/Hospital São Paulo e todas as pacientes incluídas no protocolo assinaram termo de consentimento livre e esclarecido.

\section{Coleta do DNA genômico}

O DNA genômico das pacientes foi obtido por meio de swab bucal com escova do tipo Cytobrush ${ }^{\circledR}$ seguido de bochecho com soro fisiológico $0,9 \%$. No 
laboratório, os frascos contendo o material coletado foram centrifugados a $5.000 \mathrm{rpm}$ por $5 \mathrm{~min}$; o sobrenadante foi descartado e o pellet formado foi destinado à extração do DNA genômico utilizandose o kit GFX ${ }^{T M}$ Genomic DNA Purification kit (Amersham Biosciences) seguindo as recomendações do fornecedor. O DNA genômico purificado foi mantido à temperatura de $-20^{\circ} \mathrm{C}$ até a amplificação por PCR.

\section{Reação em cadeia da polimerase (PCR)}

As condições de PCR e os oligonucleotídeos iniciadores utilizados para a detecção do polimorfismo PROGINS foram descritos anteriormente ${ }^{18,22}$. Resumidamente, as amplificações foram realizadas em volume de $25 \mathrm{~mL}$ sob condições padrões para PCR (Master Mix, Eppendorf). As condições de ciclagem foram as seguintes: desnaturação inicial a $94^{\circ} \mathrm{C}$ por 5 min e 35 ciclos de desnaturação a $94^{\circ} \mathrm{C}$ por $1 \mathrm{~min}$, anelamento a $55^{\circ} \mathrm{C}$ por $1 \mathrm{~min}$, polimerização a $72^{\circ} \mathrm{C}$ por 1 min até extensão final a $72^{\circ} \mathrm{C}$ por $7 \mathrm{~min}$. As seguintes seqüências de oligonucleotídeos iniciadores foram utilizadas para a amplificação da região que contém o polimorfismo PROGINS no intron $\mathrm{G}$ do gene do receptor de progesterona: 5'-GGC AGA AAG CAA AAT AAA AAG A-3' (primer 5') e 5'-AAA GTA TTT TCT TGC TAA ATG TC-3' (primer 3'). A amplificação da região do gene do receptor da progesterona a ser estudada pode gerar dois produtos de PCR distintos. Um, denominado P1, de 149 pb, se refere ao alelo selvagem, ou seja, sem inserção $A l u$, e outro, denominado P2, de 455 pb, resultado da inserção de 306 pb no intron G do gene do receptor. Desta forma cada paciente, ao analisarmos os dois alelos, pode ser considerada homozigota para a for-

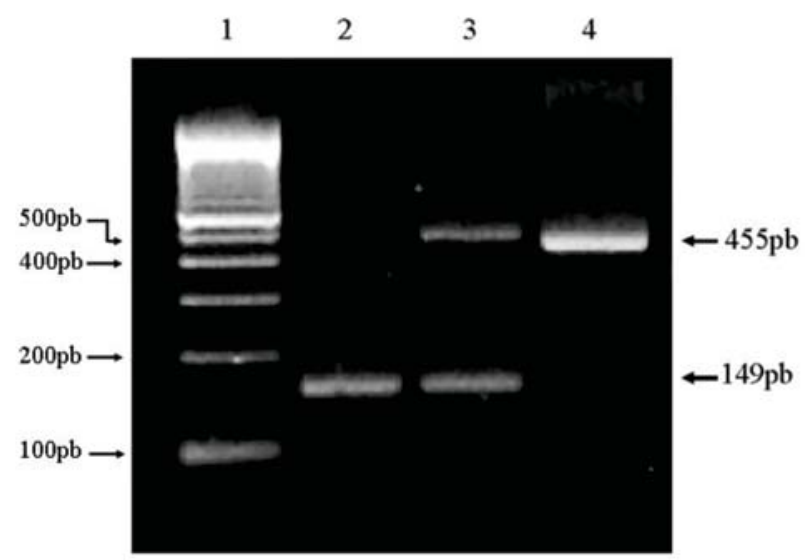

Figura 1 - Gel de agarose $2 \%$ corado com brometo de etídio contendo os possíveis genótipos para o polimorfismo PROGINS. A linha 1 contém o marcador de peso molecular 100-bp DNA ladder. As linhas 2-4 representam a amplificação da região que flanqueia o polimorfismo PROGINS do receptor de progesterona, em amostras que contêm os genótipos: homozigoto selvagem P1/1 (149 pb), heterozigoto P1/2 (149 pb e 455 pb [=149 pb+inserção Alu de 306 $\mathrm{pb}]$ ) e homozigoto polimórfico $\mathrm{P} 2 / 2(455 \mathrm{pb})$, respectivamente. ma selvagem ou polimórfica e heterozigota, contendo um alelo de cada tipo (P1/2) (Figura 1).

Foi utilizado o teste ANOVA paramétrico para análise comparativa das freqüências genotipicas entre os grupos EndoI, Endo II e controle. O teste $t$ de Student não paramétrico foi utilizado para a comparação das freqüências genotípicas entre o grupo endometriose (sem distinção por estádio clínico) e controle, considerando resultado com poder estatístico menor que 0,05.

\section{Resultados}

A freqüência de inserção PROGINS, heterozigose, foi de $18 \%$ no grupo controle, de $27 \%$ no grupo EndoI e de $38 \%$ no grupo EndoII. Ao compararmos o grupo de mulheres com endometriose nos estádios I/II com o de mulheres nos estádios III/IV observamos maior presença da inserção PROGINS nas com endometriose grave. Apenas uma paciente do grupo controle apresentou homozigose (P2/2) para o alelo polimórfico (Tabela 1). Quando comparamos, de forma conjunta, a freqüência do alelo polimórfico nas pacientes com endometriose, independente do estádio, com a freqüência no grupo controle, também observamos diferença estatisticamente significante $(p=0,0385)$ (Tabela 2).

Tabela 1 - Freqüências genotípicas para o polimorfismo PROGINS.

\begin{tabular}{lccc}
\hline & \multicolumn{3}{c}{ Genótipos } \\
& $\begin{array}{c}\text { P1/1 } \\
\text { (\%) }\end{array}$ & $\begin{array}{c}\text { P1/2 } \\
\text { (\%) }\end{array}$ & (\%) \\
\hline $\begin{array}{l}\text { Grupo Endol } \\
\text { Endometriose } \\
\text { estádios I-II } \\
\text { (n=26) }\end{array}$ & 73 & 27 & 0 \\
$\begin{array}{l}\text { Grupo Endoll } \\
\text { Endometriose } \\
\text { estádios III-IV } \\
\text { (n= 40) }\end{array}$ & & & \\
Grupo Ctr & 63 & 38 & \\
Controle \\
(n=38)
\end{tabular}

Diferença estatisticamente significante da freqüência do genótipo $\mathrm{P} 1 / 2$ entre os grupos Endol, Endoll e controle (Ctr) pelo teste ANOVA paramétrico (Endol versus Endoll < 0,001 , Endol versus $\mathrm{Ctr}<0,001$ e Endoll versus $\mathrm{Ctr}<0,05$ ). $\mathrm{P} 1 / 1$ representa 0 genótipo selvagem

P1/2 representa o genótipo heterozigoto, com um alelo contendo a inserção PROGINS $\mathrm{P} 2 / 2$ representa o genótipo homozigoto para a inserção PROGINS Apenas uma paciente do grupo controle apresentou homozigose (P2/2) para o alelo polimórfico. 
Tabela 2 - Freqüências genotípicas para o polimorfismo PROGINS em mulheres com e sem endometriose.

\begin{tabular}{lccc} 
& \multicolumn{3}{c}{ Genótipos } \\
& $\mathbf{P 1 / 1}$ & $\mathbf{P 1 / 2}$ & $\mathbf{P 2 / 2}$ \\
& $(\%)$ & $(\%)$ & $(\%)$ \\
\hline Endometriose & & 0 \\
$(\mathrm{n}=66)$ & 67 & 33 & 3 \\
Controle & & 18 & \\
(n = 38) & 79 & & \\
\hline
\end{tabular}

Diferença estatisticamente significante da freqüência do genótipo $\mathrm{P} 1 / 2$ entre os grupos endometriose e controle pelo teste $t$ de Student não paramétrico $(p=0,0385)$.

\section{Discussão}

A etiopatogenia da endometriose ainda é, até hoje, pouco conhecida; acredita-se que uma herança poligênica, multifatorial, deva estar envolvida. As alterações endometriais descritas nas enfermas são, na sua maioria, dependentes de ação inadequada da progesterona neste tecido. Este hormônio está envolvido na regulação das metaloproteinases de matriz extracelular, estimulando os fatores inibidores destas enzimas. Age também sobre a expressão de fatores angiogênicos e sobre os fatores que regulam o ciclo celular.

Dentre as causas de um distúrbio no efeito deste hormônio podemos salientar a inserção de uma seqüência de 306 pares de base no gene codificador do receptor da progesterona (PROGINS). Wieser et al. ${ }^{22}$ demonstraram correlação significativa entre esta mutação e a doença, tendo encontrado a alteração em $28 \%$ das doentes e em apenas $14 \%$ das mulheres sadias. Em nossa pesquisa observamos a inserção PROGINS em 33\% das enfermas e apenas $18 \%$ no grupo controle. Quando estudamos, de forma separada, as pacientes com endometriose estádios I/II (27\%) e as nos estádios III/IV (38\%), a diferença foi mais evidente nas com doença avançada, o que sugere que, além de possivelmente estar envolvido na gênese da doença, esse polimorfismo pode, também, influenciar a sua progressão para a forma grave.

Optamos por incluir mulheres na pós-menopausa como grupo controle, visto que na ausência na anamnese de antecedentes que sugerissem endometriose, tais como dismenorréia, infertilidade e/ou dispareunia, a probabilidade de endometriose é remota.

A influência desta anormalidade sobre a ação da progesterona, ou seja, a expressão fenotípica, já foi determinada em neoplasias de mama, de ovário e em casos de abortamento de repetição, o que nos faz supor que de alguma forma a inserção PROGINS possa também contribuir para a gênese da endometriose.

Sendo a prevalência desta inserção em mulheres com endometriose de cerca de $30 \%$, outros distúrbios devem necessariamente estar associados, o que reforça a hipótese de a doença ter origem multifatorial. Alterações (polimorfismos) da região do gene do receptor de progesterona que codificam as isoformas PRA e PRB já estão sendo estudadas, podendo estar, também, implicadas na gênese da moléstia.

A prevalência de outros polimorfismos em mulheres com endometriose tem sido verificada, na sua maioria alterações relacionadas aos genes responsáveis pela destoxificação de agentes externos, com o GST a COMT e os relacionados à família do citocromo p450, entretanto os resultados ainda são controversos.

Estudos para avaliar a prevalência de mutações gênicas e sua possivel correlação com afecções devem ser realizados em grande grupo populacional. Entretanto, sendo o estudo de Wieser et al. ${ }^{22}$ o único a avaliar a inserção PROGINS em endometrióticas, e dada a diferença significante que observamos em nossos dados preliminares, acreditamos que o achado deste polimorfismo em mulheres com endometriose justifica a publicação deste estudo visando, em futuro próximo, trabalhos em maior escala.

Vários genes devem estar possivelmente relacionados com a etiopatogenia da endometriose; acreditamos que o do receptor da progesterona possa ser um deles. Esta constatação nos permitirá, mais adiante, rastrear as mulheres com maior suscetibilidade para a doença e também avaliar e individualizar a melhor terapêutica clínica e, talvez, sua prevenção.

\section{ABSTRACT}

Objective: the aim of the present study was to verify whether there is a correlation between the prevalence of the polymorphism in the progesterone receptor gene named PROGINS and pelvic endometriosis at different stages.

Methods: a case-control study carried out from November 2003 to May 2004. The genotypes of 104 women were analyzed 66 women had had surgically confirmed endometriosis (26 women at stages I-II and 40 at stages III-IV), and 38 were healthy women. The 306-base pair Alu insertion polymorphism in the intron $G$ of the progesterone receptor gene was detected by polymerase chain reaction and analyzed on $2 \%$ agarose gel stained with ethidium bromide. ANOVA analysis was performed in order to make comparisons between among the studied groups. 
Results: the groups of women with endometriosis stages I-II (EndoI group) and stages III-IV (EndoII group) showed statistically significant increased incidence of PROGINS polymorphic allele as compared with the control group: $27 \%$ in the EndoI group, 38\% in EndoII and 18\% in the control group $(p<0.001$. In the analyses, a high frequency of the PROGINS insertion was observed in women with endometriosis as compared to healthy women, disregarding the clinical stage of the disease $(p=0.0385)$.

Conclusion: there is a significant statistical association between the PROGINS polymorphism and pelvic endometriosis.

KEYWORDS: Endometriosis. Progesterone receptor. Polymorphism.

\section{Referências}

1. Sampson JA. Peritoneal endometriosis due to the menstrual dissemination of endometrial tissue into the peritoneal cavity. Am J Obstet Gynecol 1927; 14:422-69.

2. Kruitwagen RF, Poels LG, Willemsen WN, de Ronde IJ, Jap PH, Rolland R. Endometrial epithelial cells in peritoneal fluid during the early follicular phase. Fertil Steril 1991; 55:297-303.

3. Bartosik DJ, Jacobs SL, Kelly LJ. Endometrial tissue in peritoneal fluid. Fertil Steril 1986; 46:796800.

4. Sharpe-Timms KL. Endometrial anomalies in women with endometriosis.

Ann N Y Acad Sci 2001; 943:131-47.

5. Vinatier D, Cosson M, Dufour P. Is endometriosis an endometrial disease? Eur J Obstet Gynecol Reprod Biol 2000; 91:113-25.

6. Sato H. Imunoexpressão dos anticorpos monoclonais Ki67 e Bcl2 no endométrio de mulheres com endometriose peritoneal [dissertação]. São Paulo: Univ. Federal de São Paulo; 2003.

7. Schor E. Imunoexpressão da proteína p27 no endométrio de mulheres com endometriose [tese]. São Paulo: Univ. Federal de São Paulo; 2003.

8. Jurgensen A, Mettler L, Volkov NI, Parwaresch R. Proliferative activity of endometrium throughout the menstrual cycle in infertile women with and without endometriosis. Fertil Steril 1996; 66:369-75.

9. Gebel HM, Braun DP, Tambur A, Frame D, Rana N, Dmowski WP. Spontaneous apoptosis of endometrial tissue is impaired in women with endometriosis. Fertil Steril 1998; 69:1042-7.
10.Wingfield M, Macpherson A, Healy DL, Rogers PA. Cell proliferation is increased in endometrium of women with endometriosis. Fertil Steril 1995; 64:340-6.

11.Bulun SE, Zeitoun KM, Takayama K, Sasano H. Estrogen biosynthesis in endometriosis: molecular basis and clinical relevance. J Mol Endocrinol 2000; 25:35-42.

12.Bergqvist IA. Hormonal regulation of endometriosis and the rationales and effects of gonadotrophinreleasing hormone agonist treatment: a review. Hum Reprod 1995; 10:446-52.

13. Nisolle M, Casanas-Roux F, Donnez J. Immunohistochemical analysis of proliferative activity and steroid receptor expression in peritoneal and ovarian endometriosis. Fertil Steril 1997; 68:912-9.

14.Li X, O'Malley BW. Unfolding the action of progesterone receptors. J Biol Chem 2003; 278:39261-4.

15.Mulac-Jericevic B, Mullinax RA, De Mayo FJ, Lydon JP, Conneely OM. Subgroup of reproductive functions of progesterone mediated by progesterone receptor-B isoform. Science 2000; 289:1751-4.

16.Donaldson CJ, Crapanzano JP, Watson JC, Levine EA, Batzer MA. PROGINS Alu insertion and human genomic diversity. Mutat Res 2002; 501:137-41.

17. Rowe SM, Coughlan SJ, McKenna NJ, et al. Ovarian carcinoma-associated TaqI restriction fragment length polymorphism in intron $\mathrm{G}$ of the progesterone receptor gene is due to an Alu sequence insertion. Cancer Res 1995; 55:2743-5.

18.Kurz C, Tempfer CB, Boecskoer S, Unfried G, Nagele $\mathrm{F}$, Hefler LA. The PROGINS progesterone receptor gene polymorphism and idiopathic recurrent miscarriage. J Soc Gynecol Investig 2001; 8:295-8.

19.Cramer DW, Hornstein MD, McShane P, et al. Human progesterone receptor polymorphisms and implantation failure during in vitro fertilization. Am J Obstet Gynecol 2003; 189:1085-92.

20.De Vivo I, Huggins GS, Hankinson SE, et al. A functional polymorphism in the promoter of the progesterone receptor gene associated with endometrial cancer risk. Proc Natl Acad Sci USA 2002; 99:12263-8.

21.De Vivo I, Hankinson SE, Colditz GA, Hunter DJ. A functional polymorphism in the progesterone receptor gene is associated with an increase in breast cancer risk. Cancer Res 2003; 63:5236-8.

22.Wieser F, Scheneeberger C, Tong D, Tempfer C, Huber JC, Wenzl R. PROGINS receptor gene polymorphism is associated with endometrioses. Fertil Steril 2002; 77:309-12.

23. Revised American Society for Reproductive Medicine classification of endometriosis: 1996. Fertil Steril 1997; 67:817-21.

Recebido em: 23/7/2004 Aceito com modificações em: 26/8/2004 